\section{Studia \\ z Filologii Polskiej \\ i Słowiańskiej}

DOI: $10.11649 /$ sfps.1975
Studia z Filologii Polskiej i Słowiańskiej, 55

Warszawa 2020

Article No. 1975

Citation:

Космеда, Т. А., \& Ковалевська, О. О. (2020). Нове двомовне фразеологічне видання: полемічна рефлексія. Studia z Filologii Polskiej i Słowiańskiej, 55, Article 1975. https://doi.org /10.11649/sfps.1975

Kosmeda, T. A., \& Kovalevs'ka, O. O. (2020). Nove dvomovne frazeolohichne vydannia: polemichna refleksiia. Studia z Filologii Polskiej i Słowiańskiej, 55, Article 1975. https://doi.org /10.11649/sfps.1975

Тетяна Анатоліївна Космеда (Університет імені Адама Міцкевича у Познані)

Олена Олегівна Ковалевська

(Університет імені Адама Міцкевича у Познані)

\title{
Нове двомовне фразеологічне видання: полемічна рефлексія*
}

\begin{abstract}
Рец.: Роман Тимошук, Войцех Сосновський, Мацей Яскот, Юрій Ганошенко, Лексикон польської та украӥнської активної фразеологіï, KJV Digital, Варшава 2018, 309 ss.
\end{abstract}

2018 року у варшавському видавництві KJV Digital вийшов друком Лексикон польської та української активної фразеологї̈ (Тимошук та ін., 2018; далі по тексту - Лексикон), укладений Романом Тимошуком, Войцехом Сосновським, Мацеєм Яскотом і Юрієм Ганошенком, що збагатив сучасну

* У 2019 р. вийшла коротка рецензія нашого авторства, де йдеться про аналізований у цій статті словник (див.: Космеда \& Гоменюк, 2019), зміст якої абсолютно не збігається з текстом цієї статті.

This is an Open Access article distributed under the terms of the Creative Commons Attribution 3.0 PL License (creativecommons.org/licenses/by/3.0/pl/), which permits redistribution, commercial and non-commercial, provided that the article is properly cited. (c) The Author(s) 2020.

Publisher: Institute of Slavic Studies, Polish Academy of Sciences

[Wydawca: Instytut Slawistyki Polskiej Akademii Nauk] 
двомовну фразеографічну практику новим принципом укладання словників подібного типу. Названий словник з'явився завдяки ініціативі Університету гуманітарних і соціальних наук (SWPS) за участі Українського мовно-інформаційного фонду Національної академії наук України, Інституту славістики Польської академії наук і Запорізького державного медичного університету. Спільна праця українських і польських науковців розрахована не лише на мовознавців, перекладачів, студентів філологічних спеціальностей, а й на всіх тих, хто прагне вдосконалити своє володіння українською та польською мовами, відповідно підвищити рівень своєї мовної та комунікативної компетенції, а ще цей словник розглядаємо як спробу розвитку не лише практики двомовної фразеографії, але і її теорії, оскільки концепція словника базується на нових принципах його укладання, що теоретично мотивовані.

Поява аналізованого видання зумовлена актуалізацією співпраці, яка має місце між двома дружніми сусідніми державами - Україною й Польщею, що її спостерігаємо в останні десятиліття не лише у сфері економіки чи євроінтеграційних процесів, а й у напрямку реалізації спільних освітніх та наукових проєктів. Потреба в перекладних загальномовних і термінологічних словниках постійно зростає, а доступні на ринку видання поки що однозначно не в змозі задовольнити очікування різних груп користувачів (науковців, перекладачів, економістів, юристів, лікарів, інженерів та ін.).

Розглядуваний Лексикон - це друга в історії українсько-польської та польсько-української фразеографії XXI століття спроба створення двомовного тлумачно-перекладного фразеологічного словника. У 2017 році у видавництві «Коло» (Україна) вийшов друком Короткий українсько-польський словник усталених виразів: еквіваленти слова, фразеологізми, прислів'я та приказки (Познань-Харків, 2017), укладений Тетяною Космедою, Оленою Гоменюк і Тетяною Осіповою, що став першим в історії українсько-польської фразеографії двомовним тлумачно-перекладним словником усталених виразів ${ }^{1}$. Першочергове завдання вказаного видання - це не переклад чи тлумачення мовного матеріалу, а «репрезентація еквівалентів / аналогів, розкодування лінгвокультурної інформації, закодованої в мовних знаках» (Космеда, 2017, с. 25). Словник містить грун-

1 Див. рецензію на цей словник: Михайлова \& Єсипенко, 2018. 
товну Передмову, де докладно описано його концепцію, історію поступу українсько-польської фразеографії ${ }^{2}$ сххарактеризовано досягнення в цій галузі, що зроблені попередниками, докладно викладено постулати його укладання (див.: Космеда, 2017). Цей словник налічує понад 1500 пар усталених виразів, різних за поширенням, стилістичними та жанровими характеристиками, що були відібрані з найбільш авторитетних фахових фразеографічних джерел та іншої наукової літератури, присвяченої актуальним проблемам опису українських і польських паремій. Концепція цього словника підлягала апробації в доповідях на міжнародних наукових конференціях (напр.: IV Міжнародна науково-практична конференція «Українська мова у світі», 9-10 листопада 2016 р., м. Львів) та в низці наукових публікацій (див.: Космеда та ін., 2017b). Таке обговорення сприяло покращенню відповідної концепції. Однак укладачі Лексикона не були знайомі з цим виданням, оскільки в поданій ними бібліографії назване джерело не зазначене.

Мета цієї розвідки - аналіз концепції Лексикона, укладеного Р. Тимошуком, В. Сосновським, М. Яскотом і Ю. Ганошенком, та його текстового простору, виокремлення безперечних достоїнств словника та деяких недоглядів його укладачів для того, щоб під час підготовки праці до перевидання можна було врахувати зауваження й побажання. Іншими словами, ця стаття - заклик до полеміки навколо репрезентованої концепції. Отже, виклад інформації в цьому тексті грунтується на результатах оброблення та аналізування тексту зазначеного фразеографічного видання.

Наголосимо, що для розвитку українсько-польської фразеографії мають на сьогодні велике значення словники, що вийшли друком на початку XXI століття, зокрема це: Українсько-польський словник еквівалентів слова (Київ, 2011), укладений Аллою Лучик, Ольгою Антоновою, Іоанною Дубровською (див.: Космеда, 2014) та Українсько-російсько-білорусько-польський словник порів-

2 Фразеографія включає всі типи словників усталених виразів, тобто словники, у яких подаються паремії в широкому їх трактуванні. Авторка поширеної в сучасній українській науці лінгвістичної енциклопедії Олена Селіванова з цього приводу, зокрема, пише: «Ми використовуємо широкий зміст цього терміна [ідеться про паремію - Т. К., О. К.] як одиниці фразеологічного фонду мови через наявність численних і досі не розв'язаних питань, що стосуються розмежування і кваліфікації стійких словосполук, фразем, прислів їв, приказок, етикетних сполук, крилатих висловів, складених термінів тощо» (Селіванова, 2006, с. 415). 
нянъ (Львів, 2011), укладений Оленою Левченко (див.: Мізін, 2012). Однак ці словники лише аспектуально відображають систему усталених виразів, оскільки містять: а) еквіваленти слова і б) порівняння. Назвемо й Короткий польсько-український словник прислів їв і приказок', який підготував Мар'ян Демський наприкінці XX ст., а у 2013 році упорядкувала в електронній формі його дочка Орися Демська (див.: Демський, 2013).

Українська й польська мови мають, звісно, чимало спільних рис і на лексичному, і на фонетичному чи граматичному та стилістичному рівнях, i, зрозуміло, на фразеологічному підрівні мовної системи, де всі названі ознаки простежуються. Однак така близькість, зрозуміло, часто буває оманливою, про що свідчить явище міжмовної омонімії й паронімії, що враховано укладачами Українсько-польського словника міжмовних омонімів і паронімів (Київ, 2008) Іриною Кононенко та Орестом Співаком (див.: Кочерган, 2010). Важливо, що укладачі названого видання окремо подають реєстр міжмовних фразеологічних омонімів і паронімів, хоч їх подано й небагато, зауважуючи, що розходження в семантиці цих одиниць «зумовлене не значенням окремих компонентів, а їхнім загальним змістом» (Кононенко \& Співак, 2008, с. 7).

Згадані видання засвідчують, що на початку XXI ст. українські й польські науковці досить активно працюють над укладанням двомовних українсько-польських словників. Зокрема, вони фокусують свою увагу й на зіставленні усталених виразів, що залишилися ще недостатньо дослідженими. Як наголошено у відповідних рецензіях на ці словники, теорія і практика укладання подібних видань розширюється. Зацікавлення науковців стосуються аспектуального підходу до відбору словникових одиниць, коли увага зосереджується лише на відповідному типі усталених виразів, проблема виокремлення яких ще дискутується в сучасному мовознавстві; пропонуються нові підходи до тлумачення словникових одиниць, подання до них синонімів, антонімів, омонімів та паронімів у межах однієї словникової статті та ін. Лексикон польської та української активної фразеологї, беззаперечно, мав на що спиратися (хоч його укладачі про це й не пишуть), і сам збагатив ці напрацювання насамперед новим підходом до принципів відбору словникових одиниць. Він заслуговує на критичну увагу не лише мовознавців, а й культурологів та перекладачів.

3 Однак цей словник не містить тлумачень, а пропонує лише еквіваленти, тобто він не належить до тлумачно-перекладних. 
Рецензований Лексикон складається зі вступу (сс. 7-30), польсько-української (сс. 31-148) та українсько-польської (сс. 149-268) частин, репрезентації фразеологізмів, тобто так званого індексу польських (сс. 269-287) й українських (сс. 288-306) фразеологічних одиниць, літератури (с. 307), а також інформації про авторів (сс. 308-309). Однак відзначимо певну невідповідність назв підрозділів, які пропонують автори, зокрема «Індекс польських фразеологічних одиниць» та «Індекс українських фразеологічних одиниць» містять в алфавітному порядку не перелік усталених виразів, як це повинно мало 6 мати місце, а перелік слів, що $є$ ключовими для виокремлених й описаних укладачами одиниць. Очевидно, цей недогляд легко усунути під час наступного видання вказаного словника.

У Вступі до аналізованої праці стисло описано авторську концепцію, насамперед методологію, що стала підгрунтям репрезентації $Ф О$, зокрема схарактеризовано специфіку добору та принципи тлумачення, мотивовано актуальність та обгрунтовано новизну словника, запропоновані укладачами інновації. У Вступі отримуємо інформацію, що словник загалом налічує понад 1000 одиниць. Однак зауважимо одразу, що польсько-українська й українсько-польська частини Лексикона дещо відрізняються за змістом, тобто ці частини «формувалися незалежно одна від одної», однак найбільш «активні для двох мов фразеологічні одиниці ввійшли в обидві частини» (Тимошук та ін., 2018, с. 28). Це досить оригінальний підхід до укладання двомовних словників, адже традиційно друга сторона словника безпосередньо віддзеркалює першу. Такий спосіб відбору словникових статей має певний сенс, хоч і репрезентує нетиповий підхід, вимагає більших зусиль, праці укладачів. Однак у фахівців-мовознавців виникають питання, чи такий спосіб подання матеріалу є ефективним? Напевно, однозначно це може показати лише час. Адже в цьому разі ми маємо два різні словники, що могли 6 вийти друком і окремими виданнями. Матеріал до першої частини розглядуваного Лексикона базується на найбільш активному для носіїв української мови фразеологічному мінімумі сучасного мовця й репрезентує актуальну фразеологічну картину світу українця - представника молодого і середнього покоління - з наданням польських аналогів, що не обов'язково $\epsilon$ актуальними в комунікативному просторі поляків, і не обов'язково вони включені в активний пласт їхньої фразеологічної картини світу. У другій частині все відображено цілком навпаки. 
Отже, новизна цього словника й полягає в тому, що головне завдання його авторів - відібрати найбільш активний і актуальний мінімум фразеологічної картини світу, репрезентованої в мовній свідомості українців зазначеного віку й паралельно в мовній свідомості поляків того самого віку з поданням еквівалентів у кожній із зазначених фразеологічних картин світу. Проте підібрані еквіваленти відносні, оскільки, зрозуміло, відрізняються між собою за активністю уживання. Звісно, тут не може бути абсолютного збігу, тому словниковий простір частин аналізованого словника й різний. Але це розуміє кваліфікований філолог. А пересічний носій мови очікує, що перша частина словника повинна дорівнювати його другій частині у віддзеркаленій формі. Тоді легко орієнтуватися в просторі праці.

Укладачі Лексикона зосередили увагу, як наголошувалося, на усталених виразах, що належать до активного пласту сучасної фразеології - уживаються в розмовному сучасному українському та польському мовленні, що й зазначено у Вступі, тому з метою відбору матеріалу для словника укладачі провели анкетування серед носіїв цих мов віком від 15 до 45 років.

Крім того, було проаналізовано мову засобів масової інформації реклами, газетних текстів, передусім ураховано газетні заголовки, назви художніх фільмів та серіалів, а також мовлення, характерне для електронної комунікації, якою сьогодні послуговуються носії української і польської мов, зокрема й у соціальних мережах. Утім, як видається, для більшої переконливості було б доцільно, окрім віку респондентів, указати й вид їхнього заняття, професію, належність до певної соціальної групи, місце проживання (подібну інформацію зазвичай вимагають для того, щоб соціолінгвістичні відомості були всебічними й надавали якнайдостовірнішу інформацію, необхідну для репрезентації належних висновків анкетування).

Серед усталених виразів, що зрозуміло, не знайдемо застарілих, архаїчних чи діалектних одиниць, адже репрезентовано фразеологізми, що найуживаніші в повсякденному спілкуванні носіїв польської та української мов. Це й насамперед вирізняє Лексикон від інших фразеографічних праць, названих вище.

Однак виникає питання, які критерії були ключовими під час визначення статусу актуального для сучасного мовознавства поняття «активна» фразеологія. Укладачі стверджують, що з кількох можливих варіантів 
фразеологічної одиниці, виокремлених з аналізованих матеріалів і зафіксованих у словниках, було обрано лише той, який респонденти вказали в анкетах. Але якщо опитувані подали різні варіанти усталеного виразу, тоді який з них потрапив до Лексикона? Про це інформація відсутня. Уважаємо за доцільне додати до критеріїв відбору фразеологічного матеріалу й такий, як «частотність уживання». Можливо, укладачі й ураховували певні кількісні показники, цифрові дані, але, на жаль, про це в описі добору матеріалу інформація відсутня.

Не подані в розглядуваній праці фразеологізми античного та біблійного походження, наприклад, пол.pięta achillesowa, syzyfowa praca, żebro Adama; укр. Ахіллесова п’ята, Сізібова праия, Адамове ребро, що належать до інтернаціональних, і тому вони, як показує практика й дослідження вчених, частотні в мовленні, на що вказують, наприклад, такі авторитетні фразеологи, укладачі словників біблійних фразеологізмів, як Валерій Мокієнко, Харрі Вальтер та ін. (див. Балакова та ін., 2014; Вольтер \& Мокиенко, 2010; Мокиенко, Лилич, \& Трофимкина, 2010; Мокиенко, Никитина, \& Николаева, 2010).

Укладачі словника, що розглядається, стверджують, що вони свідомо «намагалися уникати так званих фразеологічних інтернаціоналізмів» (Тимошук та ін., 2018, с. 20), але не аргументують своєї позиції. Як видається, не можна залишати ці усталені вирази поза увагою, адже однозначно не всі вони в сучасних польській та українській мовах мають ідентичне значення, часто натрапляємо на міжмовні омоніми й пароніми, що їх простежуємо саме в цій системі одиниць. До прикладу, інтернаціональний вираз альба і омега в українському лінгвокультурному просторі означає '1) початок і кінець чогось; 2) головне, основа чогось', а в польському відповіднику alfa i omega передає дещо інше значення - 'бути початком і кінцем; про людину, яка багато знає і $є$ беззаперечним авторитетом у певних справах' (Космеда та ін., 2017a, сс. 42-43).

Перевагою Лексикона, без сумніву, є послідовна фіксація фразеологічних інновацій, тобто усталених виразів, що з'явилися нещодавно й поширені в живому мовленні, які до цього часу не були відображені ані в польських, ані в українських фразеографічних виданнях. Це вважаємо одним з найбільших досягнень словника. До таких одиниць належать загальновживані фразеологізми, у структурі яких змінився один з компонентів, але семантика залишилася без змін, наприклад, пол. dostać kota в сучасному мовленні трансформувалося в dostać hopla ('у ситуації, коли щось дуже дратує людину й вона починає себе дивно поводити’) (Тимошук та ін., 2018, 
с. 49), укр. гризти землю - гризти асфальт ('хтось робить усе можливе, щоб чогось досягти') (Тимошук та ін., 2018, с. 178). Фіксація в словнику нових форм уживання фразеологізмів заслуговує на схвалення, що має значення й для фразеографічної практики, і для ії теорії, оскільки це демонструє тенденції творення фразеологічних варіантів, вектор чинності ономасіології, способи поповнення та розширення фразеологічної картини світу.

Потрапили до реєстру рецензованого видання також сленгові фразеологізми, що, за свідченням укладачів Лексикона, характеризуються високою частотністю (але конкретні цифрові показники відсутні) у сучасному молодіжному мовленні, а саме:

пол. wrzucić na luz ('у ситуації, коли хтось має заспокоїтися, розслабитися') (Тимошук та ін., 2018, с. 131),

пол. rżnać głupa ('хтось удає, що нічого не розуміє') (Тимошук та ін., 2018, c. 11),

укр. бути в темі ('коли хтось добре розуміється на чомусь') (Тимошук та ін., 2018, с. 154),

укр. дах поїхав ('у ситуації, коли хтось утрачає психічну рівновагу, божеволіє') (Тимошук та ін., 2018, с. 180).

Це факти живої національної мови, тому буде можливість згодом простежити їхню «життєву силу». Питання, чи стануть вони фактами літературної мови, чи залишаться на рівні мовлення, на сьогодні залишається відкритим.

Зафіксовані в Лексиконі й ФО зі стилістичною позначкою вульг., як-от:

пол. gówno prawda ('про щось, що є відвертою брехнею’) (Тимошук та ін., 2018, с. 54),

укр. бути в (повній) дупі ('коли хтось перебуває в скрутному становищі, має проблеми') (Тимошук та ін. 2018, с. 154).

Ці одиниці, безперечно, відображають активний пласт живого мовлення, хоч ставлення до них і не однозначне. Нагадаємо, що за концепцією класика лінгвістики Яна Бодуена де Куртене, якщо вираз функціює в мовленні, то він повинен потрапити в словник, а вже, чи потрібно його вживати, нехай вирішує користувач словника відповідно до рівня своєї культури (див. про це: Белов, 2019). Ставлення до вульгаризмів, як відомо, в українській і польській лінгвокультурах не повністю збігається. 
Принцип розміщення реєстрових одиниць у Лексиконі - алфавітний, що зручно, оскільки дає змогу швидко знайти необхідну одиницю. Графічне оформлення словникових статей має естетичний та приємний для візуального сприйняття вигляд. У кінці Лексикона для зручності користування подано, як зауважувалося, й індекс польських та українських ключових слів тих одиниць, що ввійшли до складу словника. Можна зробити висновок про характер ключових слів репрезентованих усталених виразів.

В основу Лексикона покладено поняття фразеологізму як стійкого сполучення слів, що виступає в мові як неподільна, цілісна єдність. Зокрема, до складу словника ввійшли семантично неподільні сполуки, одиниці, значення яких утратили або поступово втрачають зв'язок із семантикою їхніх компонентів, тобто ті, мотивація яких нейтралізується, особливо зважаючи на мовну компетенцію представників інших лінгвокультур; сталі сполучення слів, для яких характерна десемантизація одного з елементів, та усталені порівняння. Тут простежуємо певну методологічну неточність у виокремленні аспектів класифікації типів усталених виразів. Адже семантичний критерій базується на традиційній концепції (Шарль Баллі, Віктор Виноградов). За цим параметром виокремлюють три основних типи стійких сполучень відповідно до ступеня семантичного злиття слів, що входять до їхнього складу ${ }^{4}$. Виокремлення фразеологічних порівнянь - інший аспект класифікації. Укладачам варто було подати інформацію, що слід розуміти під фразеологічними порівняннями, які типи серед них можна виокремити, тобто окреслити їхній статус, адже він у сучасному мовознавстві неоднозначний.

Фразеологічні порівняння або, як їх ще називають, порівняльні фразеологізми, стійкі порівняння чи компаративні фразеологічні одиниці були об’єктом дослідження українських (Микола Алефіренко, Наталія Баранник, Лариса Печенікова; див. Алефіренко, 1977; Баранник, 2014; Печенікова, 2013), польських та інших закордонних мовознавців (Влодзімеж Височанський, Василь Огольцев, Олександр Кунін; див. Wysoczański, 2006; Огольцев, 1978;

${ }^{4}$ Нагадаємо, що це фразеологічні зрощення (абсолютно неподільні фразеологічні одиниці, семантика яких не має зв’язку зі значенням компонентів), фразеологічні єдноcmi (неподільні одиниці, значення яких умотивоване дещо переосмисленим значенням компонентів), фразеологічні сполучення (одиниці, семантика яких умотивована значенням компонентів, один із яких має вільне значення, а інший - зв'язане або обмежене) (Виноградов, 1977, сс. 145-161). 
Кунин, 1972). Польський мовознавець В. Височанський наголошує, що «серед усталених мовних одиниць специфічний тип становлять фразеологічні порівняння з моделлю $X$ як $Y$, що дозволяють завдяки зіставленню або порівнянню різних об’єктів, їх властивостей чи дій встановлювати співвідношення між порівнюваними елементами позамовної реальності та формувати про них судження» ${ }^{5}$ (Wysoczański, 2010, с. 158). Погоджуємося 3 досить поширеною думкою вчених про те, що порівняння мають неоднозначну кваліфікацію і з огляду на належність до відповідного типу тропів. Недостатньо аргументовано їх зазвичай відносять до найпростіших образних мовних засобів. Однак порівняння $є$ зовсім не простим для пізнання й лежить в основі моделювання інших тропів і фігур, зокрема таких, як паралелізм, метафора, метонімія, гіпербола, літота, уособлення (прозопопея, персоніфікація) тощо.

Словникові статті укладені за однаковим зразком у двох частинах Лексикона, незважаючи на те, що вони формувалися незалежно одна від одної. Схема опису фразеологізму має традиційний вигляд:

реєстрова одиниия $\rightarrow$ значення $\rightarrow$ ілюстративний матеріал / еквівалент реєстрової одиниі $\rightarrow$ значення $\rightarrow$ ілюстративний матеріал.

Під час опису фразеологізмів через скісну риску також за традицією в окремих випадках подано варіанти, наприклад:

пол. pleść / gadać / mówić / bredzić trzy po trzy,

укр. збирати / пожинати лаври,

а в круглих дужках - елементи факультативні:

укр. почуватися як (у себе) вдома,

пол. росzис́ / czuć się jak (u siebie) w domu.

Значення фразеологізмів, як стверджують укладачі, «представлені за допомогою якомога простіших синтаксичних конструкцій» (Тимошук та ін., 2018, с. 21), що можна схвалити. Однак ці конструкції не завжди репрезентують чіткість, стрункість і ясність інтерпретації, формулювання, не завжди передають усю повноту семантики відповідної одиниці та ін. Наприклад, в авторитетному Словнику фразеологізмів української мови подано три значення ідіоми сушити голову:

5 Переклад з польської мови авторський - Т. Космеда, О. Ковалевська. 
1. Напружено думати, роздумувати над чимось, шукаючи розв’язання якихось проблем. 2. Невідступно з'являтися у свідомості, турбувати, хвилювати когось (про думки). 3. Виснажувати кого-, що-небудь; ослаблювати здатність до чіткого мислення, ясного розуміння і т. ін. (Білоноженко та ін., 2008, с. 701),

а в Лексиконі - лише перше значення, навіть не в повній формі: 'тоді, коли хтось напружено думає, роздумує над чимось' (Тимошук та ін., 2018, с. 255). Отже, у тлумаченні, запропонованому укладачами розглядуваного словника, інколи простежуємо звуження семантики, що не аргументовано.

Заслуговує на безперечне схвалення факт наявності ілюстративного матеріалу, що передає значення кожного фразеологізму. Короткі, лаконічні приклади демонструють те, як правильно та доречно вживати актуалізовані фразеологізми в щоденній комунікації.

Щодо трактування в словнику поняття «еквівалентність фразеологічних одиниць», то в цьому разі, як видається, не слід бути надто категоричними, зокрема щодо інтерпретації нульової еквівалентності. Наприклад, до польської ідіоми czeski film ('wtedy, gdy nie wiadomo, о со chodzi') у Лексиконі подано описовий еквівалент: 'щось невідоме; незрозуміле; казна-що’ (Тимошук та ін., 2018, с. 46). Однак уважаємо, що ця ФО має відповідник в українській мові - чорт (гаспид, сатана) [його (тебе, ï і т. ін.]) знає (зна), що означає: «1. Невідомо, незрозуміло. 2. Уживається для вираження негативного ставлення до кого-, чого-небудь, сумніву, досади з приводу чогось» (Білоноженко та ін., 2008, с. 786). 3 огляду на відповідність з урахуванням лексичного, граматичного й семантичного рівнів - це неповний еквівалент, а згідно з класифікацією Дмитра Добровольського, на яку орієнтуються укладачі аналізованої праці, це еквівалент паралельний. Нагадаємо, що за постулатами сучасної загальновідомої й найбільш переконливої теорії перекладознавства (Михайло Алексєєнко, Роксоляна Зорівчак, Валерій Мокієнко; Алексеенко, 2001; Алексєєнко, 1993; Зорівчак, 1983; Мокиенко, 1989) у порівнюваних мовах немає фразеологічних виразів, до яких не можна було би підібрати еквівалентів. Інше питання, чи за всіма семантичними та прагматичними параметрами такі одиниці будуть рівнозначними.

Окрім тлумачення та ілюстративного матеріалу, до окремих реєстрових одиниць, що позитивно, додано стилістичні помітки, щоб допомогти користувачу визначити, у яких ситуаціях слід уживати той чи той фразеологізм. 
Однак з великої кількості існуючих стилістичних параметрів укладачі словника вибрали лише три типи стилістичних ремарок: «сленг. - сленгове», «кол. - колоквіальне», «вульг. - вульгарне». Ці помітки, зрозуміло, стосуються виключно тих одиниць, що відходять від норм літературної мови, наприклад: зіпсувати всю малину, сленг.; відкинути копита, кол.; літати як сраний віник, вульг. Проте для українського користувача не зовсім зрозумілою буде помітка «кол. - колоквіальне», адже це слово - оказіональне (індивідуально-авторське), запозичення з польської мови. Зазначена лексема відсутня в словниковому складі сучасної літературної української мови. В Uniwersalnym słowniku języka polskiego подано таке значення лексеми kolokwialny: «używany w swobodnej wypowiedzi, potocznej mowie, charakterystyczny dla takiej mowy» ${ }^{6}$ (Dubisz, 2006, с. 163). Найближчим відповідником в українській мові є слово розмовний, що його й використовують традиційно у словниках як стилістичну помітку, це прийнятий термін, що має значення: «який уживається в розмові, характерний для усного мовлення» (Бусел, 2003, с. 1063). Тому, як видається, доцільніше під час перевидання розглядуваного словника замінити позначку «кол. - колоквіальне» на «розм. - розмовне».

Крім того, у Лексиконі використано позначку «przysł. - przysłowie» / «nрик. - приказка», але укладачі не подають критеріїв розрізнення виокремлених одиниць. Однак для пересічного носія мови це й не настільки важливо (тим паче, що аналізований словник і не належить до строго академічних видань), то краще було 6 актуалізувати такі скорочення: «przysł. - przysłowie lub porzekadło», «nрисл. - прислів’я або приказка». Одиниці з такою поміткою в тексті словника, як простежуємо, зустрічаються поодиноко. Зазвичай до польського чи українського фразеологізму запропоновано відповідник, що є або прислів’ям, або приказкою (вони не розрізняються), наприклад:

cicha woda ('o kimś, kto jest pozornie spokojny, ale gotowy do nieoczekiwanych działań') - y тихому болоті чорти водяться, прик. ('про людину спокійну на вигляд, але здатну на неочікувані вчинки').

Ця приказка також зареєстрована в Короткому українсько-польському словнику усталених виразів: еквіваленти слова, фразеологізми, прислів'я та приказки, де до неї подано синонім

${ }^{6}$ Переклад українською мовою: 'використовується у вільному висловлюванні, розмовній мові, характерний для такого мовлення’. 
біжи від тієї води, яка не дзюрчить і не біжить, присл. 'про спокійну на вигляд людину, здатну на вчинки (зазвичай негативні), яких від неї важко сподіватися'

і неповний відповідник у польській мові

strzeż się tej wody, co nie szumi i nie płynie, przysł. ('o stosunkach z osobą, po której nie wiesz, czego możesz się spodziewać) (Kocмеда та ін., 2017a, с. 303).

Відмінності в репрезентації цієї одиниці зумовлені різними підходами до відбору матеріалу й пошуку відповідників: автори Лексикона зосередили увагу на пошуку найбільш активно вживаних одиниць, натомість укладачі Короткого украӥнсько-польського словника усталених виразів... мали на меті віднайти максимально наближені еквіваленти за формальними, структурно-семантичними й прагматичними параметрами.

Звернемо увагу й на те, що в тексті Лексикона (метамовна частина), на жаль, натрапляємо на випадки порушення орфографічних і стилістичних норм сучасної літературної української мови, насамперед це стосується ігнорування необхідності чергувань прийменників $y-8,3-i z$ чи префіксів $y$ - в у словах, де такі чергування необхідні, що залежить від текстових позицій, а також сполучників чи сполучних слів щзо - якиц̆, $i$ - $\breve{u}$ та ін., наприклад:

чого доброго 'тоді, коли хтось вважає щось імовірним, можливим' замість 'тоді, коли хтось уважає щось імовірним, можливим' (Тимошук та ін., 2018, с. 32);

не варто хвилюватися (описовий еквівалент) 'тоді, коли хтось вважає, що не потрібно хвилюватися у якійсь ситуації' замість 'тоді, коли хтось уважає, що не потрібно хвилюватися в якійсь ситуації (Тимошук та ін., 2018, с. 33);

бити тривогу 'тоді, коли хтось бачить небезпеку і хоче попередити про це інших' замість 'тоді, коли хтось бачить небезпеку й хоче попередити про це інших' (Тимошук та ін., 2018, с. 34);

дати / давати на лапу (комусь), кол. 'тоді, коли хтось підкуповує когось за допомогою хабара' замість 'тоді, коли хтось підкуповує когось за допомогою хабаря' (Тимошук та ін., 2018, с. 47; див.: Український правопис, 2015).

Перелік подібних недоглядів можна продовжити, тому вважаємо, що під час перевидання, необхідно здійснити фахову стилістичну й орфо- 
графічну правку цього словника, можливо, варто переглянути й факт відсутності пунктуаційних знаків під час оформлення основних частин словникових статей.

Поява таких праць, як Лексикон, безумовно, збагачує українсько-польську фразеологію, оскільки дає змогу проводити точніші паралелі, з ширшими можливостями їхнього вияву, удосконалювати підходи відбору й аналізу ФО та їхніх еквівалентів, пожвавлює наукову дискусію, розгортає полеміку щодо розвитку теорії й практики укладання подібних лексиконів. Згадані неточності та зауваження, слід розглядати як рекомендації для підготовки наступних видань Лексикона чи побажання, роздуми, що потребують осмислення, можуть обговорюватися, дискутуватися. Заслуговує на особливе схвалення введення до реєстру словника фразеологізмів, що раніше не були зафіксовані у фразеографічних працях, оскільки фразеографічна практика завжди відстає в цьому аспекті. Доступний спосіб викладу матеріалу та графічне оформлення словникових статей однозначно зможе розширити коло користувачів, які прагнуть поглибити свої знання польської та української мов.

\section{Бібліографія}

Алексеенко, М. (2001). Типы русско-украинских фразеологических соответствий (транслятологический аспект). In B. Tychoniuk (Ed.), Z badań nad wspótczesnymi językami wschodniosłowiańskimi i polskim (pp. 7-14). Wydawnictwo Wyższej Szkoły Pedagogicznej im. Tadeusza Kotarbińskiego.

Алексєєнко, М. (1993). Семантика ідіоми як основа транслятологічних відповідників. In Матеріали міжнародної наукової конференції “Семантика мови і тексту", 13-15 жовтня 1993 року (Pt. 2, pp. 1-2). Прикарпатський національний університет імені Василя Стефаника.

Алефіренко, М. (1977). Від порівняння до нового значення слова. Культура слова, 1977(13), 87-89.

Балакова, Д., Вальтер, Х., Венжинович, Н., Гутовская, М., Иванов, Е., \& Мокиенко, В. (2014). Лепта библейской мудрости: Библейские крылатые выражения и аборизмы на русском, английском, белорусском, немецком, словацком и украинском языках. Могилевский государственный университет имени А. А. Кулешова.

Баранник, Н. (2014). Сутність та структурні особливості компаративних фразеологізмів сучасної української мови. Науковий вісник Міжнародного гуманітарного університету: Філологія, 10(1), 8-11. 
Белов, И. (2019, January 21). Ян Нецислав Игнаций Бодуэн де Куртенэ - выдающийся лингвист. Culture.pl. https://culture.pl/ru/article/yan-necislav-ignaciy-boduen-de -kurtene-vydayuschiysya-lingvist

Білоноженко, В., Гнатюк, І., Дятчук, В., Неровня, Н., \& Федоренко, Т. (2008). Словник фразеологізмів української мови. Наукова думка.

Бусел, В. (Еd.). (2003). Великий тлумачний словник сучасної української мови. ВТФ “Перун”.

Виноградов, В. (1977). Избранные труды: Лексикология и лексикография. Наука.

Вольтер, Х., \& Мокиенко, В. (2010). Антипословищь русского народа (словарь). ОЛМА Медиа Групп.

Демський, М. (2013). Короткий польсько-украйнський словник прислів'їв і приказок. N.p.

Загнітко, А. (2012). Словник сучасної лінгвістики: Поняття і терміни. ДонНУ.

Зорівчак, Р. (1983). Фразеологічна одиниия як перекладознавча категорія. Вища школа.

Кононенко, І., \& Співак, О. (2008). Українсько-польський словник міжмовних омонімів і паронімів. Вища школа.

Космеда, Т. (2014). Лучик А., Антонова О., Дубровська І. Украйнсько-польський словник еквівалентів слова, К.: Виготівник ФОП Афонін А. О., 2011. - 312 c. [Review of the book]. Мовознавство, 2014(2), 85-87.

Космеда, Т. (2017). Передмова. In Т. Космеда, О. Гоменюк, \& Т. Осіпова, Короткий украінсько-польський словник усталених виразів: Еквіваленти слова, фразеологізми, прислів'я та приказки (рр. 5-30). Коло.

Космеда, Т., \& Гоменюк, О. (2019). Рецензія. Р. Тимошук, В. Сосновський, М. Яскот, Ю. Ганошенко, Лексикон польської та української активної фразеології, Варшава: KJV Digital Sp. z o. o., 2018; 309 c. Przegląd Wschodnioeuropejski, 10(2), 363-366.

Космеда, Т., Гоменюк, О., \& Осіпова, Т. (2017а). Короткий украйнсько-польський словник усталених виразів: Еквіваленти слова, фразеологізми, прислів'я та приказки. Коло.

Космеда, Т., Гоменюк, О., \& Осіпова, Т. (2017b). Українська фразеологія в польській аудиторії: Проблеми засвоєння. In Українська мова у світі: Збірник матеріалів IV Міжнародної науково-практичної конференцї: 9-10 листопада 2016 року, Львів (рp. 117-127). Видавництво Львівської політехніки.

Кочерган, М. (2010). Кононенко, І., Співак О. Украӥнсько-польський словник міжмовних омонімів і паронімів. - К.: Вища шк., 2008. - 343 с. [Review of the book]. Мовознавство, 2010(1), 100-103.

Кунин, А. (1972). Фразеология современного английского языка. Международные отношения.

Мізін, К. (2012). Левченко, О. Украӥнсько-російсько-білорусько-болгарсько-польський словник порівнянь. - Л.: Вид-во Львів. політехніки, 2011. - 748 c. [Review of the book]. Мовознавство, 2012(5), 89-92.

Мокиенко, В. (1989). Славянская фразеология. Высшая школа.

Мокиенко, В., Лилич, Г., \& Трофимкина, О. (2010). Толковый словарь библейских выражений и слов. АСТ; Астрель. 
Мокиенко, В., Никитина, Т., \& Николаева, Е. (2010). Большой словарь русских пословиц. ОЛМА Медиа Групп.

Михайлова, Т., \& Єсипенко, Д. (2018). Близькі, подібні, нетотожні: Паремійні та фразеологічні перлини у Короткому українсько-польському словнику усталених виразів. Дивослово, 2018(09(738)), 64.

Огольцев, В. (1978). Устойчивые сравнения в системе русской фразеологии. Издательство Ленинградского государственного университета.

Печенікова, Л. (2013). Компаративні фразеологічні одиниці на позначення здоров’я людини. Science and Education a New Dimension: Philology, 1/3(13), 121-123.

Селіванова, О. (2006). Сучасна лінгвістика: Термінологічна енциклопедія. Довкілля-К.

Тимошук, Р., Сосновський, В., Яскот, М., \& Ганошенко, Ю. (2018). Лексикон польської та української активної фразеологіï / Leksykon aktywnej frazeologii polskiej i ukraińskiej. KJV Digital.

Український правопис. (2015). Наукова думка.

Dubisz, S. (Ed.). (2006). Uniwersalny słownik języka polskiego: Vol. 2. K-Ó. Wydawnictwo Naukowe PWN.

Wysoczański, W. (2006). Językowy obraz świata w porównaniach zleksykalizowanych: Na materiale wybranych języków. Wydawnictwo Uniwersytetu Wrocławskiego.

Wysoczański, W. (2010). Implikowanie znaczeń przeciwstawnych i sprzecznych w porównaniach frazeologicznych. Rozprawy Komisji Językowej Wrocławskiego Towarzystwa Naukowego, 37, 157-164.

\section{Bibliography (Transliteration)}

Alefirenko, M. (1977). Vid porivniannia do novoho znachennia slova. Kul'tura slova, 1977(13), 87-89.

Alekseenko, M. (2001). Tipy russko-ukrainskikh frazeologicheskikh sootvetstviŭ (transliatologicheskiĭ aspekt). In B. Tychoniuk (Ed.), Z badań nad współczesnymi językami wschodniosłowiańskimi i polskim (pp. 7-14). Wydawnictwo Wyższej Szkoły Pedagogicznej im. Tadeusza Kotarbińskiego.

Aleksieienko, M. (1993). Semantyka idiomy iak osnova transliatolohichnykh vidpovidnykiv. In Materialy mizhnarodnoï naukovoï konferentsii "Semantyka movy i tekstu", 13-15 zhovtnia 1993 roku (Pt. 2, pp. 1-2). Prykarpats'kyi natsional'nyı universytet imeni Vasylia Stefanyka.

Balakova, D., Val'ter, K., Venzhinovich, N., Gutovskaia, M., Ivanov, E., \& Mokienko, V. (2014). Lepta biblěsskoı mudrosti: Bibleǐskie krylatye vyrazheniia i fforizmy na russkom, anglǐskom, belorusskom, nemetskom, slovatskom i ukrainskom iazykakh. Mogilevskiı̌ gosudarstvenny̆ universitet imeni A. A. Kuleshova. 
Barannyk, N. (2014). Sutnist' ta strukturni osoblyvosti komparatyvnykh frazeolohizmiv suchasnoï ukraïns'koï movy. Naukovyı visnyk Mizhnarodnoho humanitarnoho universytetu: Filolohiia, 10(1), 8-11.

Belov, I. (2019, January 21). IAn Netsislav Ignatsiŭ Boduèn de Kurtené - vydaiushchiǔsia lingvist. Culture.pl. https://culture.pl/ru/article/yan-necislav-ignaciy-boduen-de-kurtene -vydayuschiysya-lingvist

Bilonozhenko, V., Hnatiuk, I., Diatchuk, V., Nerovnia, N., \& Fedorenko, T. (2008). Slovnyk frazeolohizmiv ukraïns'koï movy. Naukova dumka.

Busel, V. (Ed.). (2003). Velykyı̆ tlumachnyı̆ slovnyk suchasnoï ukraïns'koï movy. VTF "Perun”.

Dems'kyı̆, M. (2013). Korotkyı̆ pol's'ko-ukraïns'kyı̆ slovnyk prysliv'ïv i prykazok. (n.p.).

Dubisz, S. (Ed.). (2006). Uniwersalny słownik języka polskiego: Vol. 2. K-Ó. Wydawnictwo Naukowe PWN.

Kocherhan, M. (2010). Kononenko, I., Spivak O. Ukraïns'ko-pol's'ky̆ slovnyk mizhmovnykh omonimiv i paronimiv. - K.: Vyshcha shk., 2008. - 343 s. [Review of the book]. Movoznavstvo, 2010(1), 100-103.

Kononenko, I., \& Spivak, O. (2008). Ukraïns'ko-pol's'kyı̆ slovnyk mizhmovnykh omonimiv i paronimiv. Vyshcha shkola.

Kosmeda, T. (2014). Luchyk, A., Antonova, O., Dubrovs'ka, I. Ukraïns'ko-pol's'kyı̆ slovnyk ekvivalentiv slova, K.: Vyhotivnyk FOP Afonin A. O., 2011. - 312 s. [Review of the book]. Movoznavstvo, 2014(2), 85-87.

Kosmeda, T. (2017). Peredmova. In T. Kosmeda, O. Homeniuk, \& T. Osipova, Korotky ukraïns'ko-pol's'kyı slovnyk ustalenykh vyraziv: Ekvivalenty slova, frazeolohizmy, prysliv'ia ta prykazky (pp. 5-30). Kolo.

Kosmeda, T., \& Homeniuk, O. (2019). Retsenziia. R. Tymoshuk, V. Sosnovs'kyŭ, M. IAskot, IU. Hanoshenko, Leksykon pol's'koï ta ukraïns'koï aktyvnoï frazeolohï, Varshava: KJV Digital Sp. z o.o., 2018, 309 s. Przegląd Wschodnioeuropejski, 10(2), 363-366.

Kosmeda, T., Homeniuk, O., \& Osipova, T. (2017a). Korotkyı̆ ukraïns'ko-pol's'kyı̆ slovnyk ustalenykh vyraziv: Ekvivalenty slova, frazeolohizmy, prysliv'ia ta prykazky. Kolo.

Kosmeda, T., Homeniuk, O., \& Osipova, T. (2017b). Ukraïns'ka frazeolohiia v pol's'kiǔ audytoriï: Problemy zasvoiennia. In Ukraïns'ka mova u sviti: Zbirnyk materialiv IV Mizhnarodnoï naukovo-praktychnoï konferentsii: 9-10 lystopada 2016 roku, L'viv (pp. 117-127). Vydavnytstvo L'vivs'koï politekhniky.

Kunin, A. (1972). Frazeologiia sovremennogo angliŭskogo iazyka. Mezhdunarodnye otnosheniia.

Mizin, K. (2012). Levchenko, O. Ukraïns'ko-rosiǔs'ko-bilorus'ko-bolhars'ko-pol's'ky̆ slovnyk porivnian'. - L.: Vyd-vo L'viv. politekhniky, 2011. - 748 s. [Review of the book]. Movoznavstvo, 2012(5), 89-92.

Mokienko, V. (1989). Slavianskaia frazeologiia. Vysshaia shkola.

Mokienko, V., Lilich, G., \& Trofimkina, O. (2010). Tolkovyı̌ slovar' bibleı̌skikh vyrazheniǔ i slov. AST; Astrel'. 
Mokienko, V., Nikitina, T., \& Nikolaeva, E. (2010). Bol'shoĭ slovar' russkikh poslovits. OLMA Media Grupp.

Mykhaŭlova, T., \& IEsypenko, D. (2018). Blyz'ki, podibni, netotozhni: Paremiüni ta frazeolohichni perlyny u Korotkomu ukraïns'ko-pol's'komu slovnyku ustalenykh vyraziv. Dyvoslovo, 2018(09(738)), 64.

Ogol'tsev, V. (1978). Ustoŭchivye sravneniia v sisteme russkoŭ frazeologii. Izdatel'stvo Leningradskogo gosudarstvennogo universiteta.

Pechenikova, L. (2013). Komparatyvni frazeolohichni odynytsi na poznachennia zdorov'ia liudyny. Science and Education a New Dimension: Philology, 1/3(13), 121-123.

Selivanova, O. (2006). Suchasna linhvistyka: Terminolohichna entsyklopediia. Dovkillia-K.

Tymoshuk, R., Sosnovs'kyı̆, V. [Sosnowski, W.], IAskot [Jaskot], M., \& Hanoshenko, I. (2018). Leksykon pol's'koï ta ukrä̈n'koï aktyvnoï frazeolohiï / Leksykon aktywnej frazeologii polskiej i ukraińskiej. KJV Digital.

Ukraïns'kyı pravopys. (2015). Naukova dumka.

Vinogradov, V. (1977). Izbrannye trudy: Leksikologiia i leksikografiia. Nauka.

Vol'ter, K., \& Mokienko, V. (2010). Antiposlovitsy russkogo naroda (slovar'). OLMA Media Grupp.

Wysoczański, W. (2006). Językowy obraz świata w porównaniach zleksykalizowanych: $\mathrm{Na}$ materiale wybranych języków. Wydawnictwo Uniwersytetu Wrocławskiego.

Wysoczański, W. (2010). Implikowanie znaczeń przeciwstawnych i sprzecznych w porównaniach frazeologicznych. Rozprawy Komisji Językowej Wrocławskiego Towarzystwa Naukowego, 37, 157-164.

Zahnitko, A. (2012). Slovnyk suchasnoï linhvistyky: Poniattia i terminy. DonNU.

Zorivchak, R. (1983). Frazeolohichna odynytsia iak perekladoznavcha katehoriia. Vyshcha shkola.

\section{A New Bilingual Phraseological Dictionary: A Polemical Reflection}

\section{Summary}

This article presents a critical analysis of the bilingual publication entitled A Lexicon of Polish and Ukrainian Active Phraseology (Leksykon aktywnej frazeologii polskiej i ukraińskiej / Leksykon pol's'koï ta ukraïns'koï aktyvnoï frazeolohii), compiled by Roman Tymoshuk, Wojciech Sosnowski, Maciej 
Jaskot and Yurii Ganoshenko. In the history of Ukrainian-Polish and PolishUkrainian phraseography of the twenty-first century, this is the second attempt at creating a bilingual phraseological dictionary, following the publication of A Concise Ukrainian-Polish Dictionary of Set Expressions: Lexical Equivalents, Phraseologisms, Proverbs and Sayings (Korotky̌ ukraïns'ko-pol's'kyı slovnyk ustalenykh vyraziv: Ekvivalenty slova, frazeolohizmy, prysliv'ia ta prykazky, Poznań and Kharkiv, 2017), compiled by Tetiana Kosmeda, Olena Homeniuk and Tetiana Osipova.

The distinctive feature of the reviewed dictionary is that it contains phraseologisms which are most widely used in everyday speech. The compilers developed an original conception: (1) Polish-Ukrainian and UkrainianPolish parts differ in content, as they were compiled independently, yet most popular phraseologisms are included in both parts; (2) the most representative set expressions in active use in both languages were selected on the basis of questionnaires and mass media material; (3) entries include illustrative material; (4) it has an optimal size - about 1,000 phraseological units.

On the other hand, the dictionary also has some drawbacks, such as: (1) it lacks key criteria for determining the status of the notion "active" phraseology; (2) it does not include slang phraseologisms which do not belong to literary language; (3) the meanings of phraseological units are described by means of simple syntactic structures which lack consistent criteria of clarity and comprehensibility of interpretation, and the dictionary does not cover all semantic potential and pragmatic information of the listed units; (4) excessively categorical interpretation of the notion zero equivalence; (5) not all entries contain stylistic labels, and those used are only of three types: slang, colloquial, vulgar; the label przyslowie/nриказка (proverb) seems incorrect, as the compilers do not provide criteria of its separate status; (6) metalanguage of the dictionary is marked with some violations of orthographic and stylistic norms. Nevertheless, the dictionary has undoubtedly enriched the theory of phraseography, phraseographic practice and found its users. 


\title{
Polemiczna refleksja na temat nowego dwujęzycznego słownika frazeologicznego
}

\author{
Streszczenie
}

Niniejszy artykuł przedstawia analizę krytyczną dwujęzycznego Leksykonu aktywnej frazeologii polskiej i ukraińskiej (Лексикон польської та української активної фразеологіi), autorstwa Romana Tymoshuka, Wojciecha Sosnowskiego, Macieja Jaskota i Yuriia Ganoshenki. Jest to drugi dwujęzyczny słownik frazeologiczny w historii ukraińsko-polskiej i polsko-ukraińskiej frazeografii XXI wieku, po Małym ukrainsko-polskim słowniku utrwalonych wyrażeń językowych: Ekwiwalenty, frazeologizmy, powiedzenia i przysłowia (Короткий украӥнсько-польський словник усталених виразів: еквіваленти слова, фразеологізми, прислів'я та приказки, Poznań-Charków 2017) Tetiany Kosmedy, Oleny Homeniuk i Tetiany Osipovej.

Cechą wyróżniającą recenzowany słownik jest jego zawartość - frazeologizmy powszechnie używane ca co dzień. Autorzy zastosowali oryginalną koncepcję, w myśl której: (1) pomimo że część polsko-ukraińska i ukraińsko-polska mają różną zawartość, powstawały bowiem niezależnie, każda z nich zawiera najbardziej popularne frazeologizmy; (2) najbardziej reprezentatywne wyrażenia wybrano na podstawie badań kwestionariuszowych i materiałów ze środków masowego przekazu; (3) hasła zawierają przykłady ilustrujące ich użycie; (4) słownik ma optymalną wielkość: zawiera około tysiąca jednostek frazeologicznych.

Z drugiej zaś strony, słownik ma również pewne niedociągnięcia, wśród których należy wymienić: (1) brak określenia kluczowych elementów pojęcia „aktywna” frazeologia; (2) nieuwzględnienie wyrażeń slangowych nienależących do języka literackiego; (3) opis znaczeń frazeologizmów za pomocą prostych struktur syntaktycznych, którym brak spójnych kryteriów jasności i zrozumiałości interpretacyjnej, co sprawia, że słownik nie w pełni uwzględnia potencjał semantyczny i informację pragmatyczną przedstawianych wyrażeń; (4) zbyt kategoryczna interpretacja pojęcia brak ekwiwalencji; (5) nie wszystkie hasła są opatrzone kwalifikatorami stylistycznymi, a lista tych ostatnich ogranicza się jedynie do trzech: slang, potoczne, wulgarne; kwalifikator przysłowiel приказка wydaje się niepoprawny, jako że autorzy nie podają kryteriów, na 
podstawie których go wyodrębniono; (6) metajęzyk słownika cechuje się pewnymi naruszeniami norm ortograficznych i stylistycznych. Niemniej jednak słownik z pewnością wzbogacił teorię frazeografii i praktykę frazeograficzną, oraz spotkał się z zainteresowaniem ze strony użytkowników.

Keywords: bilingual phraseography; phraseological dictionary; theory of phraseography; phraseographic practice

Słowa kluczowe: frazeografia dwujęzyczna; słownik frazeologiczny; teoria frazeografii; praktyka frazeograficzna

(1) Tetiana Kosmeda, Adam Mickiewicz University, Poznań, Poland

ORCID: http://orcid.org/0000-0001-8912-2888

Correspondence: tkosmeda@gmail.com

(2) Olena Kowalewska, Adam Mickiewicz University, Poznań, Poland ORCID: http://orcid.org/0000-0003-1241-449X

Correspondence: gomeniuk.olena@gmail.com

Authors' contribution: The following declarations about the particular authors' contributions to this work have been made: concept of the study: first author; data analyses: second author; drafting the manuscript: first and second author.

The preparation of this article was financed within the statutory activities of the Institute of Russian and Ukrainian Studies, Adam Mickiewicz University in Poznań.

Competing interests: The authors have declared they have no competing interests. Tetiana Kosmeda is a reviewer in this issue of the journal. 